\title{
Brunneodinemasporium jonesii and Tainosphaeria jonesii spp. nov. (Chaetosphaeriaceae, Chaetosphaeriales) from southern China
}

\author{
Lu YZ ${ }^{1-3}$, Liu KJ ${ }^{4}$, Hyde KD ${ }^{2}$, Bhat DJ ${ }^{5-6}$, Xiao YP ${ }^{1-2}$, Tian $Q^{2}$, Wen TC ${ }^{1}$, Boonmee \\ $\mathrm{S}^{2}$, Kang $\mathrm{JC}^{1^{*}}$
}

${ }^{I}$ The Engineering and Research Center for Southwest Bio-Pharmaceutical Resources of National Education Ministry of China, Guizhou University, Guiyang, Guizhou Province 550025, P.R. China

${ }^{2}$ Center of Excellence in Fungal Research, Mae Fah Luang University, Chiang Rai 57100, Thailand

${ }^{3}$ School of Pharmaceutical Engineering, Guizhou Institute of Technology, Guiyang 550003, P.R. China

${ }^{4}$ Guizhou Key Laboratory of Agricultural Biotechnology, Guizhou Academy of Agricultural Sciences, Guiyang, Guizhou Province 550006, P.R. China

${ }^{5}$ Formerly, Department of Botany, Goa University, Goa, India

${ }^{6}$ No. 128/1-J, Azad Housing Society, Curca, Goa Velha-403108, India

Lu YZ, Liu JK, Hyde KD, Bhat DJ, Xiao YP, Tian Q, Wen TC, Boonmee S, Kang JC 2016 Brunneodinemasporium jonesii and Tainosphaeria jonesii spp. nov. (Chaetosphaeriaceae, Chaetosphaeriales) from southern China. Mycosphere 7 (9), 1323-1332, Doi 10.5943/mycosphere/7/9/6

\begin{abstract}
A study of the fungi of Guangxi Province, China revealed two novel species, namely Brunneodinemasporium jonesii and Tainosphaeria jonesii which are introduced in this paper. Molecular analysis based on combined ITS and LSU sequence data showed that 1) Brunneodinemasporium jonesii formed a distinct clade with the type species B. brasiliense and is therefore introduced as the second species in this monotypic genus; 2) The isolates of Tainosphaeria jonesii clustered together with $T$. crassiparies and $T$. siamensis, and showed a close relationship with T. siamensis, but is a phylogenetically distinct species. It is herein described as the third species of Tainosphaeria. Morphological examination showed that 1) Brunneodinemasporium jonesii differs from the generic type species as its conidia have mucilaginous balls at each end, which are aggregated in chains, arising from conidiogenous cells that are aggregated into conspicuous slimy, dome-shaped masses; 2) Tainosphaeria jonesii is characterized by its mononematous conidiophores, phialidic conidiogenous cells with funnel-shaped collarettes at the apices and conidia with single unbranched, flexuous, tubular appendages at each end. Descriptions, illustrations and molecular analyses are provided for these new species.
\end{abstract}

Keywords - New species - phylogeny - Sordariomycetes - taxonomy - woody fungi

\section{Introduction}

The order Chaetosphaeriales was introduced in Sordariomycetidae by Huhndorf et al. (2004) based on molecular phylogenetic analysis of LSU sequence data. Chaetosphaeriales comprises two families, Chaetosphaeriaceae and Helminthosphaeriaceae with 38 and seven genera respectively (Maharachchikumbura et al. 2015, 2016, Liu et al. 2016). The genera Brunneodinemasporium and 
Tainosphaeria belong to the family Chaetosphaeriaceae.

The monotypic genus Brunneodinemasporium was introduced by Crous et al. (2012) with $B$. brasiliense Crous \& R.F. Castañeda as the type species, to accommodate a dinemasporium-like species with tightly aggregated brown conidiogenous cells and pale brown conidia. According to Crous et al. (2012), Brunneodinemasporium differs from Dinemasporium in having randomly distributed setae throughout the basal stroma. Dinemasporium on the other hand, has a denselyaggregated layer of brown conidiogenous cells, with a prominent periclinal thickening and apically tapering conidia, that are pale brown, and have setae that are separated from the conidia by a septum (Crous et al. 2012, Liu et al. 2015). Brunneodinemasporium are saprobic on decaying leaves (Crous et al. 2012).

The genus Tainosphaeria was introduced by Fernández \& Huhndorf (2005) based on the type species T. crassiparies F.A. Fernández \& Huhndorf. It is characterized by subglobose to ovoid ascomata, simple, septate, hyaline paraphyses, unitunicate, cylindrical, pedicellate asci, with an apical ring, and hyaline, septate ascospores. Fernández \& Huhndorf (2005) suggested that Tainosphaeria bears morphological similarities and is phylogenetically close to Zignoëlla. The asexual morph of Tainosphaeria resembles Chloridium, Codinaea, Striatosphaeria and Zignoëlla (Fernández et al. 2005). The asexual morph resembles Chloridium matsushimae W. Gams \& Hol.Jech. in the percurrent proliferations of the conidiogenous cell and the setulose conidia. It also resembles Codinaea aristata Maire in the terminal integrated conidiogenous cell, conspicuous funnel-shaped collarette and terminally setulate conidia. Liu et al. (2016) studied the family Chaetosphaeriaceae and described a second species named T. siamensis from freshwater in Thailand. Tainosphaeria species are reported as saprobic on decaying or submerged wood (Fernández \& Huhndorf 2005, Liu et al. 2016).

In this paper, we introduce a novel Brunneodinemasporium species and one new Tainosphaeria species based on morphology and phylogenetic analysis.

\section{Materials and Methods}

Sample collection and specimen examination

Decaying wood samples were randomly collected from sampling sites in flowing freshwater streams of Guangxi Province, China. Samples were returned to the laboratory in Zip-lock plastic bags. The material was examined with a Motic SMZ 161 series stereo-microscope. Micromorphological structures were photographed using a Nikon ECLIPSE Ni compound microscope fitted with a Canon EOS 600D digital camera and measurements made using Tarosoft (R) Image Frame Work program (Liu et al. 2010). Figures were processed with an Adobe Photoshop CS6 Extended version 10.0 software (Adobe Systems, USA).

Single spore isolations were obtained using the method described by Chomnunti et al. (2014). Germinating spores were aseptically transferred to fresh potato-dextrose agar (PDA) media and incubated at $25-30{ }^{\circ} \mathrm{C}$. The type specimens and ex-type living cultures are deposited in the Herbarium of Guizhou Academy of Agricultural Sciences (Herb. GZAAS) and Guizhou Culture Collection (GZCC), Guiyang, China respectively. Facesoffungi and Index Fungorum numbers are provided (Jayasiri et al. 2015, Index Fungorum 2016).

DNA extraction, PCR amplification and sequencing

Genomic DNA was extracted from fungal mycelium grown on PDA at $28{ }^{\circ} \mathrm{C}$ for 30 days. Two genes were amplified with universal primers, namely the internal transcribed spacer region of ribosomal DNA (ITS: ITS5/ITS4) (White et al. 1990), large subunit nuclear ribosomal DNA (LSU: LROR/LR5) (Vilgalys \& Hester 1990). The PCR products were purified and sequenced with the same primers. The amplification reactions were carried out with the following protocol refs: The final volume of the PCR reaction was $50 \mu \mathrm{l}$ which contained $2 \mu \mathrm{l}$ of DNA template, $2 \mu \mathrm{l}$ of each forward and reverse primers, $25 \mu$ of $2 \times$ Bench Top ${ }^{\mathrm{TM}}$ Taq Master Mix (mixture of Taq DNA Polymerase, dNTPs, and $\mathrm{MgCl}_{2}$; Solarbio life sciences, Beijing, P. R. China) and $19 \mu$ of sterilized water. The 
PCR thermal cycle program for ITS gene amplification was provided as: initially $95{ }^{\circ} \mathrm{C}$ for 3 min, followed by 34 cycles of denaturation at $95{ }^{\circ} \mathrm{C}$ for $30 \mathrm{~s}$, annealing at $51{ }^{\circ} \mathrm{C}$ for $1 \mathrm{~min}$, elongation at $72{ }^{\circ} \mathrm{C}$ for $45 \mathrm{~s}$, and final extension at $72{ }^{\circ} \mathrm{C}$ for $10 \mathrm{~min}$. The PCR thermal cycle program for LSU gene amplification were provided as: initially $95^{\circ} \mathrm{C}$ for $3 \mathrm{~min}$, followed by 30 cycles of denaturation at $94{ }^{\circ} \mathrm{C}$ for $30 \mathrm{~s}$, annealing at $51{ }^{\circ} \mathrm{C}$ for $50 \mathrm{~s}$, elongation at $72{ }^{\circ} \mathrm{C}$ for $1 \mathrm{~min}$, and final extension at 72 ${ }^{\circ} \mathrm{C}$ for $7 \mathrm{~min}$. The quality of PCR products were checked on $1 \%$ agarose gel electrophoresis strained with ethidium bromide. The PCR products were send for sequencing at Sangon Biotech, Shanghai, China.

Table 1 Isolates used in this study and their ITS and LSU GenBank accession numbers

\begin{tabular}{|c|c|c|c|}
\hline \multirow{2}{*}{ Taxon } & \multirow{2}{*}{ Culture No. } & \multicolumn{2}{|c|}{ GenBank Accession No. } \\
\hline & & LSU & ITS \\
\hline Brunneodinemasporium brasiliense & CBS 112007 & JQ889288 & JQ889272 \\
\hline Brunneodinemasporium jonesii & GZCC 16-0050 & KY026055 & KY026058 \\
\hline Chaetosphaeria preussii & CBS 262.76 & AF178561 & $-^{\mathrm{a}}$ \\
\hline Chloridium lignicola & CBS 143.54 & AF178544 & AF178544 \\
\hline Codinaeopsis gonytrichoides & CBS 593.93 & AF178556 & AF178556 \\
\hline Dendrophoma cytisporoides & CBS 223.95 & JQ889289 & JQ889273 \\
\hline Dictyochaeta siamensis & MFLUCC 15-0614 & KX609952 & KX609955 \\
\hline Dinemasporium decipiens & CBS 592.73 & JQ889291 & JQ889275 \\
\hline Dinemasporium morbidum & CBS 129.66 & JQ889296 & JQ889280 \\
\hline Dinemasporium morbidum & CBS 995.97 & JQ889297 & JQ889281 \\
\hline Dinemasporium strigosum & CBS 828.84 & JQ889299 & JQ889283 \\
\hline Ellisembia brachypus & HKUCC 10555 & DQ408563 & - \\
\hline Exserticlava vasiformis & TAMA 450 & AB753846 & - \\
\hline Infundibulomyces cupulata & BCC11929 & EF113979 & - \\
\hline Infundibulomyces oblongisporus & BCC 13400 & EF113980 & - \\
\hline Lasiosphaeria ovina & SMH4605 & AY436413 & - \\
\hline Lecythothecium duriligni & CBS 101317 & AF261071 & - \\
\hline Melanochaeta aotearoae & SMH 3551 & AF466082 & - \\
\hline Melanochaeta hemipsila & SMH 2125 & AY346292 & - \\
\hline Melanochaeta taitensis & GKM156N & EU583220 & - \\
\hline Melanochaeta taitensis & GKM150N & EU583219 & - \\
\hline Melanopsammella gonytrichii & SMH 3785 & AF466085 & - \\
\hline Melanopsammella vermicularioides & FC 404 & AF466087 & - \\
\hline Menispora tortuosa & DAOM 231154 & AY544682 & KT225527 \\
\hline Menispora tortuosa & CBS 214.56 & AF178558 & AF178558 \\
\hline Menisporopsis theobromae & MFLUCC 15-0055 & KX609954 & KX609957 \\
\hline Neopseudolachnella acutispora & MAFF 244358 & AB934041 & AB934065 \\
\hline Neopseudolachnella magnispora & MAFF 244359 & AB934042 & AB934066 \\
\hline Neopseudolachnella uniseptata & MAFF 244360 & AB934043 & AB934067 \\
\hline Pseudodinemasporium fabiforme & MAFF 244361 & AB934044 & AB934068 \\
\hline Pseudolachnea hispidula & MAFF 244364 & AB934047 & AB934071 \\
\hline Pseudolachnea fraxini & CBS 113701 & JQ889301 & JQ889287 \\
\hline Pseudolachnella botulispora & MAFF 244367 & AB934050 & AB934074 \\
\hline Pseudolachnella scolecospora & MAFF 244379 & AB934062 & AB934086 \\
\hline Pyrigemmula aurantiaca & CBS 126743 & HM241692 & HM241692 \\
\hline Pyrigemmula aurantiaca & CBS 126744 & HM241693 & HM241693 \\
\hline Rattania setulifera & GUFCC 15501 & HM171322 & GU191794 \\
\hline Tainosphaeria crassiparies & SMH 1934 & AF466089 & - \\
\hline Tainosphaeria siamensis & MFLUCC15-0607 & KX609953 & KX609956 \\
\hline Tainosphaeria jonesii & GZCC 16-0053 & KY026056 & KY026059 \\
\hline Tainosphaeria jonesii & GZCC 16-0065 & KY026057 & KY026060 \\
\hline Thozetella nivea & - & EU825200 & EU825201 \\
\hline Umbrinosphaeria caesariata & CBS 102664 & AF261069 & - \\
\hline Zignoëlla pulviscula & MUCL 15710 & AF466090 & - \\
\hline Zignoëlla pulviscula & SMH 3289 & AF466091 & - \\
\hline
\end{tabular}

Notes - New isolates are in bold. ${ }^{a}$ No data in GenBank. 


\section{Phylogenetic analysis}

The sequenced taxa were determined using nucleotide BLAST searches online in GenBank (http://www.ncbi.nlm.nih.gov/) and those in recent papers on the family and genera studied herein (Crous et al. 2012, Ariyawansa et al. 2015, Liu et al. 2015, 2016, Maharachchikumbura et al. 2015, 2016). The combined alignments of ITS and LSU sequence data from the closest relatives in Chaetosphaeriaceae were used to generate phylogenetic placements. Lasiosphaeria ovina (strain SMH 4605) was used as the outgroup taxon. The sequence accessions in the analysis are provided in Table 1. The sequence data were aligned using MAFFT v.7.110 online program (http://mafft.cbrc.jp/alignment/server/) (Katoh \& Standley 2013), and manually adjustment in BioEdit 7.2.3 (Hall 1999). Maximum likelihood (ML) and Bayesian inference (BI) were used in analyses with individual data from each partition in addition to the combined aligned dataset.

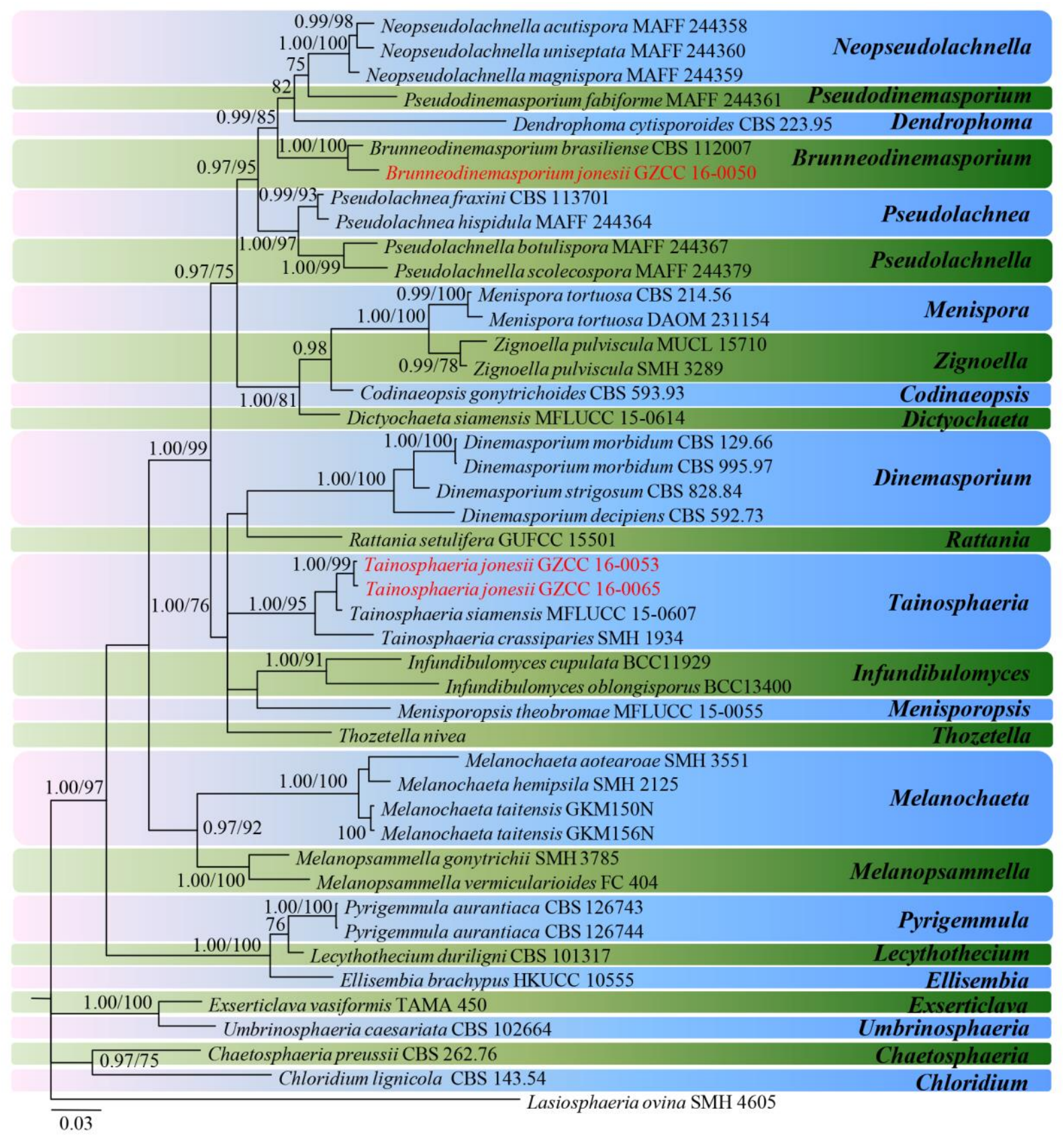

Fig. 1 - Consensus phylogram (50\%) majority rule resulting from a Bayesian analysis of a combined ITS and LSU sequence alignment. Bayesian posterior probabilities greater than 0.95 (PP) and RAxML bootstrap support values greater than $75 \%$ (BS) are shown at the nodes. The tree is rooted with Lasiosphaeria ovina SMH 4605 (Lasiosphaeriaceae). New isolates are in red. 
The phylogeny website tools "ALTER" (Glez-Peña et al. 2010) were used to transfer the alignment file from Nexus to Phy file for RAxML analysis. Maximum likelihood (ML) analysis was performed at the CIPRES Science Gateway v. 3.3 (http://www.phylo.org/portal2/, Miller et al. 2010) using RAxML v.8.2.8 as part of the "RAxML-HPC BlackBox" tool (Stamatakis 2006; Stamatakis et al. 2008). All free model parameters will be estimated by RAxML and ML estimate of 25 per site rate categories. Final ML search were conducted use the GTRGAMMA + I model. Bootstrap support values (BS) equal or greater than $75 \%$ are given above each node (Fig. 1).

Bayesian analysis was carried out using MrBayes v.3.1.2 (Ronquist \& Huelsenbeck 2003). The best-fit model of sequences evolution was estimated by using MrModeltest 2.2 (Nylander 2004). Markov Chain Monte Carlo sampling (BMCMC) in MrBayes v.3.0b4 (Huelsenbeck \& Ronquist 2001) were used to determine the Posterior probabilities (PP) (Rannala \& Yang 1996; Zhaxybayeva \& Gogarten 2002). Phylogenetic trees were sampled every 100th generation (resulting in 10,000 total trees) in 1,000,000 generations from the running of six simultaneous Markov chains. The first 2,000 trees which contained the burn-in phase of the analyses were discarded. The remaining 8,000 trees were used to calculate the posterior probabilities (PP) in the majority rule consensus tree. Bayesian posterior probabilities with those equal or greater than 0.95 are given below each node (Fig. 1). Phylogenetic trees were visualized using FigTree v1.4.0 (http://tree.bio.ed.ac.uk/software/figtree/, Rambaut 2012). The sequences are deposited in GenBank (Table 1). The alignment was deposited in TreeBASE (http://www.treebase.org, submission number 20263).

\section{Results and Discussion}

Phylogenetic analysis of combined LSU and ITS sequence data

Three isolates of hyphomycetes obtained from the incubated specimens of decaying wood were identified in the family Chaetosphaeriaceae. ITS and LSU sequence data and morphological characters were used to assign the species and to describe novel taxa with a comparison with similar taxa (Crous et al. 2012, Liu et al. 2016).

The combined sequence dataset of ITS and LSU was analyzed by using ML and Bayesian analyses (Fig. 1). All trees were similar in topology and did not differ significantly (data not shown). The combined sequence alignment comprised 45 taxa, including our new strains. Bootstrap support values of RAxML $(\geq 75 \%)$ are shown on the upper branches (Fig. 1). Values of the Bayesian PP $(\geq 0.95)$ from MCMC analyses are shown below the branches.

One of our three isolates clustered with Brunneodinemasporium brasiliense in a well-supported clade, but is phylogenetically and morphologically distinct and is introduced as B. jonesii sp. nov. in this paper. Two morphologically similar, but phylogenetically different isolates to Tainosphaeria siamensis are identified as $T$. jonesii sp. nov.

\section{Taxonomy}

Brunneodinemasporium jonesii Y.Z. Lu, J.K. Liu \& K.D. Hyde, sp. nov.

Fig. 2

Index Fungorum number: IF 552516

Facesoffungi number: FoF 02638

Holotype - GZAAS 16-0062

Etymology - Named in honour of Professor E.B. Gareth Jones for his contributions to tropical mycology.

Saprobic on decaying wood in freshwater stream. Asexual morph: Conidiomata on woody substrate, mostly scattered or sometimes in groups of $2-3$, superficial, globose to subglobose, becoming cupulate when dry, sporodochial, unilocular, dark brown to black, with a white to buff slimy conidial mass in center, setose. Basal stroma with cells of textura angularis. Setae abundant, brown to black, simple, straight, septate, wide at base, acute at apex, unbranched, smooth, thick- 

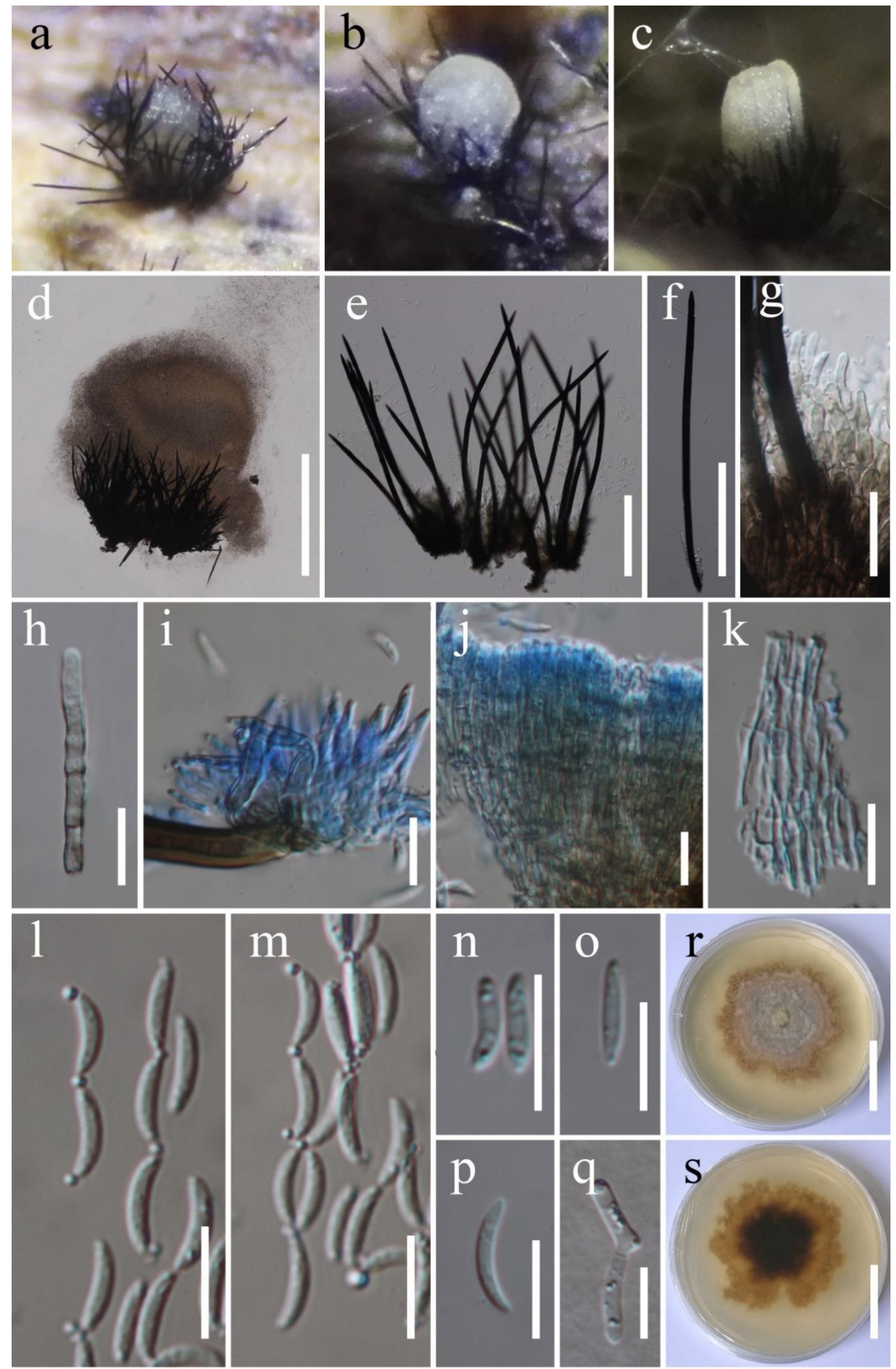

Fig. 2 - Brunneodinemasporium jonesii (GZAAS 16-0062, holotype). a-c Conidiomata on host surface. d Conidioma. e-f Conidioma setae. $\mathrm{g}-\mathrm{h}$ Conidiophores and conidiogenous cells. $\mathrm{i}-\mathrm{k}$ Basal stroma of conidioma and conidiophores stained with cotton blue. 1-p Conidia (Note: conidia are connected by mucilaginous balls). q Germinating conidium. $\mathrm{r}-\mathrm{s}$ Colonies on PDA from above and below. - Scale bars: $\mathrm{d}=500 \mu \mathrm{m}, \mathrm{e}-\mathrm{f}=100 \mu \mathrm{m}, \mathrm{g}=20 \mu \mathrm{m}, \mathrm{h}-\mathrm{q}=10 \mu \mathrm{m}, \mathrm{r}-\mathrm{s}=20 \mathrm{~mm}$. 
walled, 178-290 $\mu \mathrm{m}$ long, 5-7.5 $\mu \mathrm{m}$ wide, arising from basal stroma. Conidiophores lining the basal stroma into a densely-packed mass, brown, multi-septate, unbranched or branched, cylindrical, thinwalled, smooth, 53-71 $\times 1.3-2 \mu m(\bar{x}=63 \times 1.7 \mu m, \mathrm{n}=20)$. Conidiogenous cells integrated, determinate, phialidic with a collarette and clear periclinal thickening at apex, pale brown, smooth, subcylindrical to lageniform, $6.5-13 \mu \mathrm{m}$ long $\times 1-2.5 \mu \mathrm{m}$ wide $(\bar{x}=9 \times 1.8 \mu \mathrm{m}, \mathrm{n}=50)$. Conidia hyaline to subhyaline, aseptate, thin-walled, smooth, fusiform, straight or curved, obtuse to subobtusely rounded at apex, truncate to rounded at the base, aguttulate or guttulate, $6-9.5 \times 1.5-2$ $\mu m$ wide $(\bar{x}=8 \times 1.7 \mu m, \mathrm{n}=50)$, with mucilaginous balls released at the conidial ends; connecting the conidia in short false chains. Chains of conidia arising from conidiogenous cells aggregated into a conspicuous slimy, dome-shaped mass. Sexual morph: not observed.

Culture characteristics - Conidia germinating on water agar (WA) within $24 \mathrm{~h}$ and germ tubes produced from conidium. Colonies growing on potato dextrose agar medium (PDA), form irregular, surface rough, edge undulate, reaching $30 \mathrm{~mm}$ in two weeks at $28^{\circ} \mathrm{C}$, initially pale brown and changing to brown when aged. Mycelium superficial and partially immersed, branched, septate, hyaline to pale brown, smooth.

Material examined - CHINA, Guangxi Province, Fang Cheng Gang, on decaying wood in a freshwater stream, 15 May 2016, Yong-Zhong Lu, JHC17-1 (GZAAS 16-0062, holotype); ex-type living culture, GZCC 16-0050.

Notes - Brunneodinemasporium jonesii is introduced here as a novel species based on morphological distinctions and phylogenetic analysis. Combined LSU and ITS sequence data recognize $B$. jonesii as belonging to the genus Brunneodinemasporium and formed a distinct clade with the type species B. brasiliense with high support (100\% BS and 1.00 PP) (Fig. 1). Morphologically, these two species are similar in conidiophores and setae, but they differ from each other by conidia shape. Brunneodinemasporium brasiliense have a single, unbranched, flexuous, tubular appendage at each end, but $B$. jonesii lacks this feature. Instead, the conidia are connected by mucilaginous balls in $B$. jonesii. Therefore, we introduced $B$. jonesii as the second species of Brunneodinemasporium.

Tainosphaeria jonesii Y.Z. Lu, J.K. Liu \& K.D. Hyde, sp. nov.

Fig. 3 Index Fungorum number - IF 552517

Facesoffungi number - FoF 02639;

Holotype - GZAAS 16-0065

Etymology - Named in honour of Professor E.B. Gareth Jones for his contributions to tropical mycology.

Saprobic on decaying wood in freshwater stream. Mycelium composed of partly immersed and partly superficial, hyaline to pale brown, septate, with glistening conidial masses. Asexual morph: Conidiophores 44-98 (113) $\mu \mathrm{m}$ long 2.5-3.5 $\mu \mathrm{m}$ wide $(\bar{x}=71 \times 3 \mu \mathrm{m}, \mathrm{n}=20)$, superficial, mononematous, macronematous, crowded, erect, unbranched, dark brown below half, pale brown towards the apex, septate, unbranched, smooth-walled, tapering to a terminal, single phialide. Conidiogenous cells phialidic, proliferating percurrently, subcylindrical, light brown, narrowing below the collarette. Collarettes light brown, funnel-shaped, 3.5-5 $\mu \mathrm{m}$ at the opening, 1.5-3 $\mu \mathrm{m}$ deep. Conidia $14-19 \times 2-3 \mu \mathrm{m}$ wide $(\bar{x}=17 \times 2.5 \mu \mathrm{m}, \mathrm{n}=50)$, hyaline, aseptate, thin-walled, smooth, fusiform, gently curved, rarely straight, obtuse to subobtusely rounded at the apex, truncate at base, eguttulate or guttulate, with single, unbranched, 6-8.5 $\mu \mathrm{m}$ long, flexuous, tubular appendage at each end, apparently separated from the conidium by a septum. Sexual morph: Undetermined.

Culture characteristics - Conidia germinating on water agar (WA) within $12 \mathrm{~h}$ and germ tubes produced from conidium. Colonies growing on potato dextrose agar medium (PDA), irregular, surface rough, edge undulate, reaching $30 \mathrm{~mm}$ in two weeks at $28^{\circ} \mathrm{C}$, initially brown then becoming dark brown gradually, but greenish-brown in the center all the times. Mycelium superficial and partially immersed, branched, septate, hyaline to pale brown, smooth. 

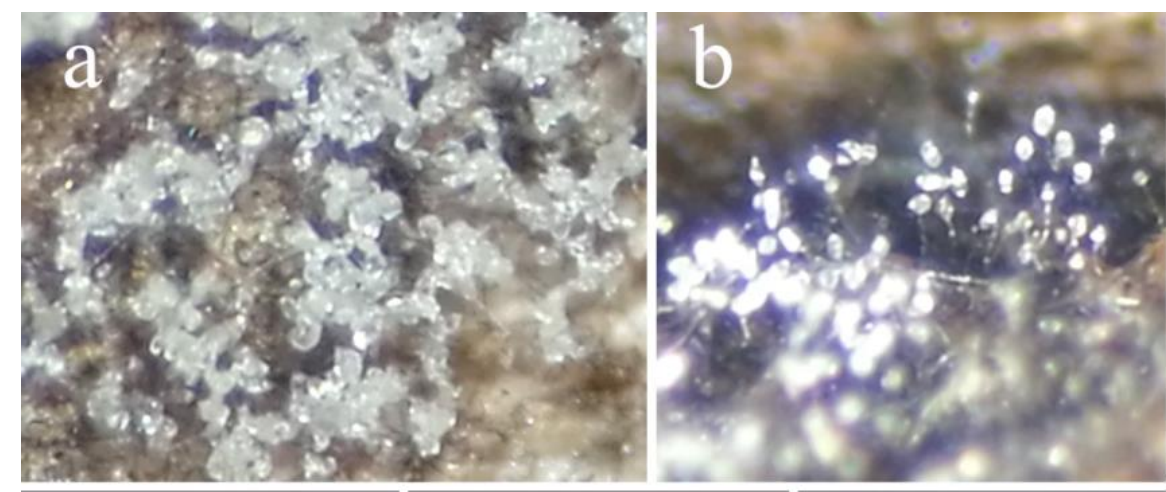

d
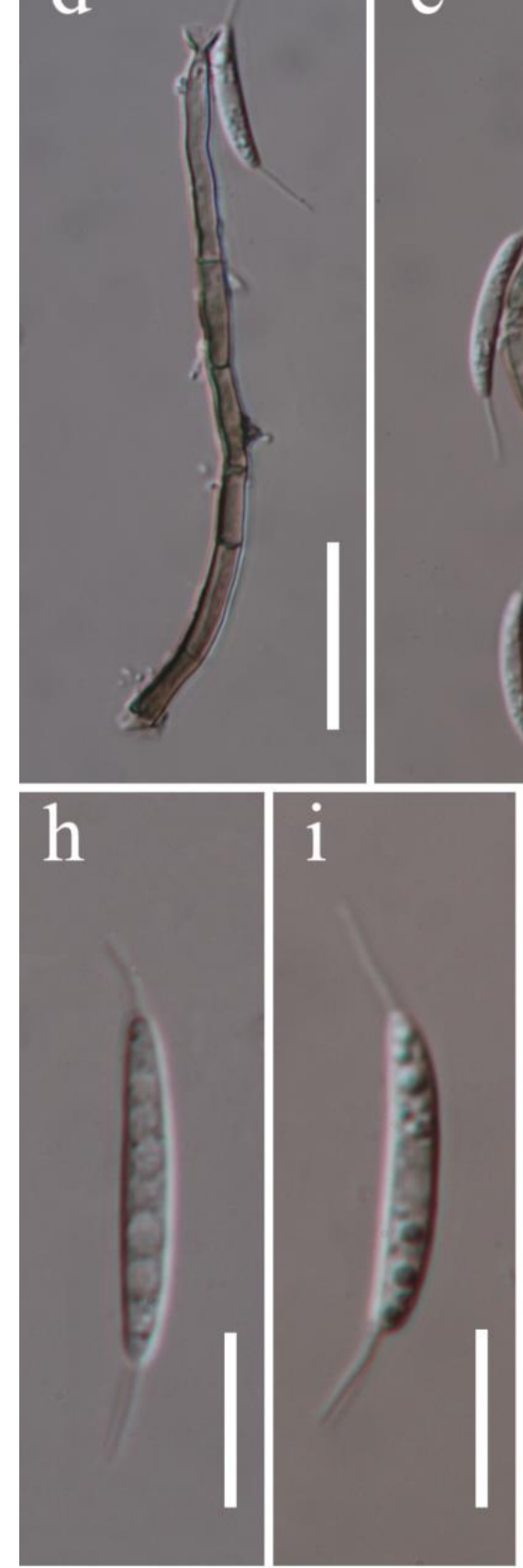
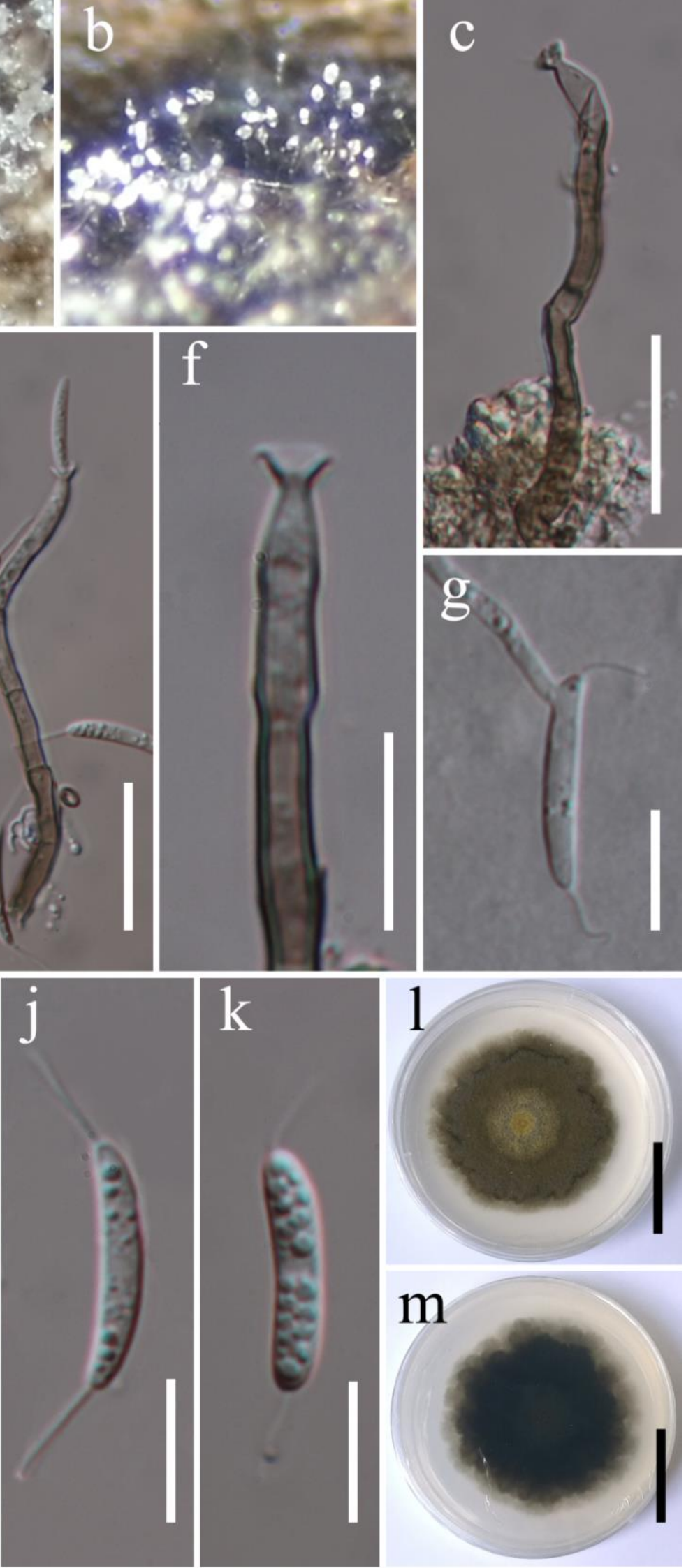

Fig. 3 - Tainosphaeria jonesii (GZAAS 16-0065, holotype). a-b Conidia on host surface. c Conidiophore on host substrate. d Conidiophores with conidium. e Phialide with a developing conidium. f Apical phialide. g Germinating conidium. $\mathrm{h}-\mathrm{k}$ Conidia. $1-\mathrm{m}$ Colonies on PDA from above and below. - Scale bars: $\mathrm{c}-\mathrm{e}=20 \mu \mathrm{m}, \mathrm{f}-\mathrm{k}=10 \mu \mathrm{m}, \mathrm{l}-\mathrm{m}=20 \mathrm{~mm}$. 
Material examined - CHINA, Guangxi Province, Fang Cheng Gang, on decaying wood in freshwater stream, 15 May 2016, Yong-Zhong Lu, JHC 21-4 (GZAAS 16-0065, holotype); ex-type living culture, GZCC 16-0053. CHINA, Guangxi Province, He Chi, on decaying wood in a mountain, 19 May 2016, Yong-Zhong Lu, ML 06-2 (GZAAS 16-0077); living culture, GZCC 16-0065.

Notes - Two strains of Tainosphaeria jonesii were isolated from the specimens collected from Guangxi Province, China. This is the first record of Tainosphaeria for China, while the other two previously described species were from Puerto Rico and Thailand (Fernández \& Huhndorf 2005, Liu et al. 2016). Tainosphaeria jonesii was found as an asexual morph on natural woody substrates, and is morphologically similar to T. siamensis. However, the phylogeny (Fig. 1) indicates that they are different species. Although the statistical support (70\% BS / 0.90 PP, data not shown) is not reach to the significant standard (75\% BS / $0.95 \mathrm{PP}$ ), this might cause by the population of the genus, as well as only two genes included. However, from the topology it clearly showed that they could be phylogenetically distinct species. Moreover, we also compared the new species with Tainosphaeria siamensis by using single gene, and there are $7 \mathrm{bp}$ and $10 \mathrm{bp}$ differences in LSU and ITS respectively which also confirmed that they are phylogenetically distinct species even though they share similar morphology. Therefore, we introduced it as a novel Tainosphaeria species.

\section{Acknowledgments}

This work was funded by the grants of the National Natural Science Foundation of China (NSFC Grant No. 31460011) and the agricultural science and technology foundation of Guizhou province (Nos. NY[2013]3042) from the Science and Technology Department of Guizhou province, China. J.K Liu would like to thank the Phylogeny and Biodiversity of Botryosphaeriaceae in Southwest China (Qian KeHe LH 2015-7061).

\section{References}

Ariyawansa HA, Hyde KD, Jayasiri SC, Buyck B et al. 2015 - Fungal diversity notes 111-252taxonomic and phylogenetic contributions to fungal taxa. Fungal Diversity 75, 27-274.

Chomnunti P, Hongsanan S, Hudson BA, Tian Q et al. 2014 - The sooty moulds. Fungal Diversity $66,1-36$.

Crous PW, Verkley GJM, Christensen M, Castañeda-Ruiz RF, Groenewald JZ. 2012 - How important are conidial appendages?. Persoonia 28, 126-137.

Fernández FA, Huhndorf SM. 2005 - New species of Chaetosphaeria, Melanopsammella and Tainosphaeria gen. nov. from the Americas. Fungal Diversity 18, 15-57.

Glez-Peña D, Gómez-Blanco D, Reboiro-Jato M, Fdez-Riverola F, Posada D. 2010 - ALTER: program-oriented conversion of DNA and protein alignments. Nucleic Acids Research 38, 14 18.

Hashimoto A, Sato G, Matsuda T, Matsumura M et al. 2015 - Taxonomic revision of Pseudolachnea and Pseudolachnella and establishment of Neopseudolachnella and Pseudodinemasporium gen. nov. Mycologia 107, 383-408.

Huelsenbeck JP, Ronquist F. 2001 - MRBAYES: Bayesian inference of phylogenetic trees. Bioinformatics 17, 754-755.

Huhndorf SM, Miller AN, Fernández FA. 2004 - Molecular systematics of the Sordariales: the order and the family Lasiosphaeriaceae redefined. Mycologia 96, 368-387.

Index Fungorum. 2016 - http://www.indexfungorum.org/names/Names.asp.

Jayasiri SC, Hyde KD, Ariyawansa HA, Bhat DJ et al. 2015 - The Faces of Fungi database: fungal names linked with morphology, phylogeny and human impacts. Fungal Diversity 74, 3-18.

Katoh K, Standley DM. 2013 - MAFFT multiple sequence alignment software version 7: improvements in performance and usability. Molecular Biology and Evolution 30, 772-780.

Liu JK, Chomnunti P, Cai L, Phookamsak R et al. 2010 - Phylogeny and morphology of Neodeightonia palmicola sp. nov. from palms. Sydowia 62, 261-276. 
Liu JK, Hyde KD, Jones EBG, Ariyawansa HA et al. 2015 - Fungal diversity notes 1-110: taxonomic and phylogenetic contributions to fungal species. Fungal Diversity 72, 1-197.

Liu JK, Yang J, Maharachchikumbura SSN, McKenzie EHC et al. 2016 - Novel chaetosphaeriaceous hyphomycetes from aquatic habitats. Mycological Progress 15, 11571167.

Maharachchikumbura SSN, Hyde KD, Jones EBG, McKenzie EHC et al. 2016 - Families of Sordariomycetes. Fungal Diversity 79, 1-317.

Maharachchikumbura SSN, Hyde KD, Jones EBG, McKenzie EHC et al. 2015 - Towards a natural classification and backbone tree for Sordariomycetes. Fungal Diversity 72, 199-301.

Miller MA, Pfeiffer W, Schwartz T. 2010 - Creating the CIPRES Science Gateway for inference of large phylogenetic trees. In Proceedings of the Gateway Computing Environments Workshop 2010 (GCE), pp 1-8.

Nylander JAA. 2004 - MrModeltest 2.0. Program distributed by the author. Evolutionary Biology Centre, Uppsala University.

Rambaut A. 2012 - FigTree version 1.4.0. Available at http://tree.bio.ed.ac.uk/software/figtree.

Rannala B, Yang Z. 1996 - Probability distribution of molecular evolutionary trees: a new method of phylogenetic inference. Journal of Molecular Evolution 43, 304-311.

Ronquist F, Huelsenbeck JP. 2003 - MrBayes 3: Bayesian phylogenetic inference under mixed models. Bioinformatics 19, 1572-1574.

Stamatakis A. 2006 - RAxML-VI-HPC: maximum likelihood-based phylogenetic analyses with thousands of taxa and mixed models. Bioinformatics 22, 2688-2690.

Stamatakis A, Hoover P, Rougemont J. 2008 - A rapid bootstrap algorithm for the RAxML webservers. Systematic Biology 75, 758-771.

Vilgalys R, Hester M. 1990 - Rapid genetic identification and mapping of enzymatically amplified ribosomal DNA from several Cryptococcus species. Journal of Bacteriology 172, 4238-4246.

White TJ, Bruns T, Lee S, Taylor JW. 1990 - Amplification and direct sequencing of fungal ribosomal RNA genes for phylogenetics. PCR protocols: a guide to methods and applications $18,315-322$.

Zhaxybayeva O, Gogarten JP. 2002 - Bootstrap, Bayesian probability and maximum likelihood mapping: exploring new tools for comparative genome analyses. BMC Genomics 3, 1. 